\title{
Inhibitory Effect of Loranthus parasiticus on IgE-Mediated Allergic Responses in RBL-2H3 Cells
}

\author{
Jae-Myung Yoo, Ju-Hye Yang, Young Soo Kim, Won-Kyung Cho, and Jin Yeul Ma \\ Korean Medicine (KM) Application Center, Korea Institute of Oriental Medicine (KIOM), Daegu 41062, Republic of Korea \\ Correspondence should be addressed to Won-Kyung Cho; wkcho@kiom.re.kr and Jin Yeul Ma; jyma@kiom.re.kr
}

Received 1 May 2016; Revised 18 July 2016; Accepted 9 August 2016

Academic Editor: Patrick Geraghty

Copyright ( 2016 Jae-Myung Yoo et al. This is an open access article distributed under the Creative Commons Attribution License, which permits unrestricted use, distribution, and reproduction in any medium, provided the original work is properly cited.

\begin{abstract}
The mistletoe Loranthus parasiticus has been used as a compound for traditional medicine in Northeast Asia for a long time and is known to possess neuroprotective action. Nonetheless, the effect of Loranthus parasiticus on allergic responses remains unknown. In the present study, we evaluated whether the water extract of Loranthus parasiticus (LPE) could inhibit IgE-mediated allergic responses in RBL-2H3 cells. LPE inhibited the release of $\beta$-hexosaminidase $\left(\mathrm{IC}_{50}, 184.5 \mu \mathrm{g} / \mathrm{mL}\right.$ ) and the formation of tumor necrosis factor- $\alpha\left(\mathrm{IC}_{50}, 84.27 \mu \mathrm{g} / \mathrm{mL}\right)$, interleukin- $4\left(\mathrm{IC}_{50}, 93.43 \mu \mathrm{g} / \mathrm{mL}\right)$, prostaglandin $\mathrm{E}_{2}\left(\mathrm{IC}_{50}, 84.10 \mu \mathrm{g} / \mathrm{mL}\right)$, prostaglandin $\mathrm{D}_{2}$, and leukotriene $\mathrm{C}_{4}\left(\mathrm{IC}_{50}, 43.27 \mu \mathrm{g} / \mathrm{mL}\right)$ in a concentration-dependent manner. Moreover, LPE inhibited phosphorylation of Syk, PLC $\gamma 1 / 2$, PKC $\delta$, ERK, JNK, p38, and Akt. In the late phase, LPE decreased 5-lipoxygenase phosphorylation and COX-2 expression but not cPLA 2 phosphorylation. Additionally, LPE included total phenolic compounds ( $10.72 \mathrm{mg} / \mathrm{g}$ dry weight) and total flavonoids $(56.20 \mathrm{mg} / \mathrm{g}$ dry weight). These results suggest that the phenolic compounds or flavonoids contained in LPE may be associated with antiallergic activity. The phenolic compounds and flavonoids in LPE are antiallergic phytochemicals capable of inhibiting the activation of the FceRI signaling cascade in mast cells. Such effects may provide further information for the development of a phytomedicine for allergic diseases.
\end{abstract}

\section{Introduction}

Mistletoe, a semiparasitic plant, is widely distributed across the globe and has been used as a constituent of traditional medicine in Northeast Asia for centuries [1]. Five species of mistletoe are widely distributed in the Republic of Korea. Viscum album L., known as European mistletoe, and Loranthus parasiticus, known as Mulberry mistletoe, are mainly used for traditional medicine in the Republic of Korea [2]. Mistletoe possesses various beneficial effects, such as anticancer, antiobesity, neuroprotection, antioxidant, and anti-inflammation activities [3]. The extract of Viscum album L., known as Iscador, has been used in anticancer therapy in Europe because it possesses strong anticancer action [4]. Such effects of mistletoe are associated with various bioactive compounds, including lectins, viscotoxins, triterpenes, sesquiterpene lactones, flavonoids, and phenolic compounds [5]. Nonetheless, the biological effect of Loranthus parasiticus is still unknown with the exception of its neuroprotective effects [6].
Anaphylactic shock is a type I allergy that is closely associated with acute inflammation [7]. The inflammatory response is associated with the degranulation of immunoglobulin E(IgE-) sensitized mast cells or basophilic cells [8]. These cells express FceRI receptors known as the high-affinity $\operatorname{IgE}$ receptor located on the plasma membrane [8]. When IgEsensitized mast cells are stimulated by antigens, the cells liberate various inflammatory mediators, including tumor necrosis factor- $\alpha$ (TNF- $\alpha$ ), interleukin-4 (IL-4), prostaglandin $\mathrm{E}_{2}\left(\mathrm{PGE}_{2}\right)$, prostaglandin $\mathrm{D}_{2}\left(\mathrm{PGD}_{2}\right)$, and leukotriene $\mathrm{C}_{4}$ $\left(\mathrm{LTC}_{4}\right)$ with $\beta$-hexosaminidase, a biomarker of degranulation, through activation of the FceRI signaling cascade [8-10]. Moreover, $\mathrm{PGD}_{2}$ and $\mathrm{LTC}_{4}$ are involved in chronic inflammation in asthma or allergic rhinitis $[11,12]$. Therefore, anaphylactic shock is very important clinically.

In this study, we found that the extract of Loranthus parasiticus (LPE) possessed antiallergic activity in IgE-mediated allergic responses in mast cells and demonstrate how LPE inhibits allergic responses in the above cells. In conclusion, 
the results may provide further information for the development of a phytomedicine for allergic diseases.

\section{Materials and Methods}

2.1. Reagents. MEM- $\alpha$ medium, $1 \mathrm{x}$ DPBS, fetal bovine serum (FBS), penicillin, and streptomycin were purchased from GE Healthcare Life Sciences (Hyclone ${ }^{\mathrm{TM}}$, Logan, UT, USA). The EZ-Cytox cell viability assay kit was obtained from DAEILLAB SERVICE Co. (Seoul, Korea). Specific antibodies against phospho-protein kinase B (Akt; \#9271), phospho-cytosolic phospholipase $\mathrm{A}_{2}$ (cPLA $;$;2831), phospho-extracellular signal-regulated kinase 1/2 (ERK; \#9101), phospho-c-Jun $N$ terminal kinase 1/2 (JNK; \#9251), phospho-Src family protein kinase (Lyn; \#2731), phospho-p38 (\#9211), phosphoprotein kinase C $\delta$ (PKC $\delta$; \#2055), phospho-phospholipase C $\gamma 1 / 2$ (PLC $\gamma 1 / 2 ; \# 2821$, \#3871, resp.), and phospho-spleen tyrosine kinase (Syk; \#2710) and cyclooxygenase-2 (COX-2; \#4842) were obtained from Cell Signaling Technology, Inc. (Beverly, MA, USA). Specific antibodies against phosphofeline yes-related protein (Fyn; orb128087) and $\beta$-actin (sc47778) were obtained from Biorbyt Ltd. (Cambridge, UK) and Santa Cruz Biotechnology, Inc. (Dallas, TX, USA), respectively. A specific antibody against 5-lipoxygenase (5LO; 10007820) and EIA kits for $\mathrm{LTC}_{4}, \mathrm{PGD}_{2}$, and $\mathrm{PGE}_{2}$ were obtained from Cayman Chemical Co. (Ann Arbor, MI, USA). ELISA kits for IL- 4 and TNF- $\alpha$ were purchased from e-Bioscience, Inc. (Science Center Drive, San Diego, USA). Dinitrophenyl-human serum albumin (DNP-HSA), DNPIgE, Folin-Ciocalteu reagent, caffeic acid, diethylene glycol, quercetin, and 4-nitrophenyl $N$-acetyl- $\beta$ - $D$-glucosaminide (p-NAG) were purchased from Sigma-Aldrich Co. (St. Louis, MO, USA). All other chemicals for this study were of analytical grade.

2.2. Preparation of Loranthus parasiticus Extract. LPE was prepared according to a modification of a process reported previously [13]; Loranthus parasiticus was obtained from the Yeongcheon Oriental Herbal Market (Yeongcheon, Korea) and then identified by Dr. Ki-Hwan Bae, a Professor Emeritus at the College of Pharmacy, Chungnam National University (Daejeon, Korea). Loranthus parasiticus (1 kg) was boiled in distilled water (10 liter) for approximately $3 \mathrm{~h}$ at $115^{\circ} \mathrm{C}$. The aqueous extract was filtered through a testing sieve (Aperture $500 \mu \mathrm{m}$ and $150 \mu \mathrm{m})$. The filtered extract was filtered through a $60 \mu \mathrm{m}$ nylon net filter (Millipore, MA, USA) and deposited overnight. The supernatant was lyophilized, and then the dried pellet was stored at $-20^{\circ} \mathrm{C}$ until use. The powder of LPE was dissolved in 10\% dimethyl sulfoxide (DMSO) solution for all experiments.

2.3. Determination of Total Phenolic and Flavonoid Compounds. The amounts of total phenolic compounds and flavonoids in LPE were evaluated following previously reported methods [14]. LPE powder was dissolved using $20 \mathrm{mM}$ PBS buffer ( $\mathrm{pH}$ 7.4) to a final concentration of $100 \mathrm{mg} / \mathrm{mL}$. The solution $(0.33 \mathrm{~mL})$ was mixed with $2.5 \mathrm{~mL}$ of distilled water and then incubated with $0.16 \mathrm{~mL}$ of FolinCiocalteu reagent for $5 \mathrm{~min}$. The above solution was further incubated for 30 min in darkness after treatment with $10 \%$ sodium bicarbonate solution $(0.3 \mathrm{~mL})$. The absorbance at $760 \mathrm{~nm}$ was measured using a microplate reader (SpectraMax i3, Molecular devices, CA, USA). A standard curve was prepared to express the results as caffeic acid equivalents. Separately, to determine amounts of total flavonoids in LPE, $0.4 \mathrm{~mL}$ of LPE was added to $4 \mathrm{~mL} 90 \%$ diethylene glycol containing $0.4 \mathrm{~mL}$ of $1 \mathrm{~N} \mathrm{NaOH}$, and then the mixture was incubated for $1 \mathrm{~h}$. The absorbance of the solution at $420 \mathrm{~nm}$ was measured using a microplate reader. A standard curve was prepared to express the results as quercetin equivalents.

2.4. Cell Culture. RBL-2H3 cells, a mast cell line originating from rat basophilic leukemia [15], were cultured in MEM- $\alpha$ medium including $10 \%$ FBS and antibiotics $(100 \mathrm{U} / \mathrm{mL}$ penicillin and $100 \mu \mathrm{g} / \mathrm{mL}$ streptomycin) at $37^{\circ} \mathrm{C}$ in a humidified atmosphere of $5 \% \mathrm{CO}_{2}$. All the experiments contain a control group as a vehicle control group containing 0.1\% DMSO.

2.5. Cell Viability Assay. Cell viability was evaluated by measuring the mitochondrial-dependent conversion from WST-1 to water-soluble tetrazolium salt [16]. In brief, RBL$2 \mathrm{H} 3$ cells were seeded on a 96-well plate $\left(1 \times 10^{4}\right.$ cells/well $)$ in MEM- $\alpha$ medium containing $10 \%$ FBS at $37^{\circ} \mathrm{C}$ overnight. The above cells were washed with $1 \mathrm{x}$ DPBS and then incubated with $50 \mathrm{ng} / \mathrm{mL}$ DNP-IgE. After $24 \mathrm{~h}$, IgE-sensitized cells were preincubated with LPE ( 0 to $400 \mu \mathrm{g} / \mathrm{mL}$ ) in MEM- $\alpha$ medium with $1 \%$ FBS for $1 \mathrm{~h}$, simultaneously mixed with $0.1 \mu \mathrm{g} / \mathrm{mL}$ DNP-HSA and $10 \mu \mathrm{L}$ EZ-Cytox reagent, and then further incubated for $4 \mathrm{~h}$. The cell viability of the above cells was determined by a microplate reader $(450 \mathrm{~nm})$.

2.6. $\beta$-Hexosaminidase Activity Assay. $\beta$-Hexosaminidase activity assay was performed following the previously reported method [17]. Supernatant $(25 \mu \mathrm{L})$ was added to $50 \mu \mathrm{L}$ p-NAG $(10 \mathrm{mM})$ in $0.1 \mathrm{M}$ sodium citrate buffer $(\mathrm{pH} 4.5)$ and then incubated for $1 \mathrm{~h}$ at $37^{\circ} \mathrm{C}$. The reaction was finished by $0.1 \mathrm{M}$ sodium carbonate buffer ( $\mathrm{pH} 10.0)$. The absorbance was measured at $405 \mathrm{~nm}$ using a microplate reader.

2.7. Enzyme-Linked Immunosorbent Assay for IL-4 and TNF$\alpha$. To determine the amounts of TNF- $\alpha$ or IL- 4 in cultured media, IgE-sensitized cells were preincubated with LPE in MEM- $\alpha$ medium with $1 \%$ FBS for $1 \mathrm{~h}$ and then stimulated with DNP-HSA for $4 \mathrm{~h}$. All cultured media were centrifuged $(17,000 \times \mathrm{g})$ for $10 \mathrm{~min}$ at $4^{\circ} \mathrm{C}$, and then the samples were stored at $-80^{\circ} \mathrm{C}$ until use. IL- 4 and TNF- $\alpha$ were evaluated by ELISA kits according to the manufacturer's instruction.

2.8. Enzyme Immunoassay Analysis for $L T C_{4}, P G D_{2}$, and $P G E_{2}$. To measure the levels of $\mathrm{PGD}_{2}, \mathrm{PGE}_{2}$, or $\mathrm{LTC}_{4}$ in cultured media, all samples were centrifuged and stored at $-80^{\circ} \mathrm{C}$ until use. $\mathrm{LTC}_{4}, \mathrm{PGD}_{2}$, and $\mathrm{PGE}_{2}$ and were measured by EIA kits according to the manufacturer's instruction.

2.9. Immunoblotting Analysis. Immunoblotting analysis was determined using the previous method [17]. Blotted membranes were visualized using the ECL plus kit as a chemiluminescent reagent (Bio-Rad, Hercules, CA, USA) with 


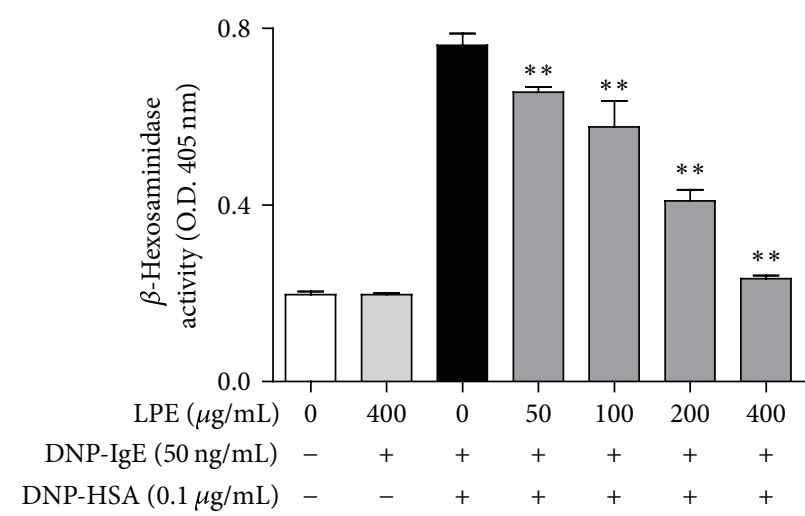

(a)

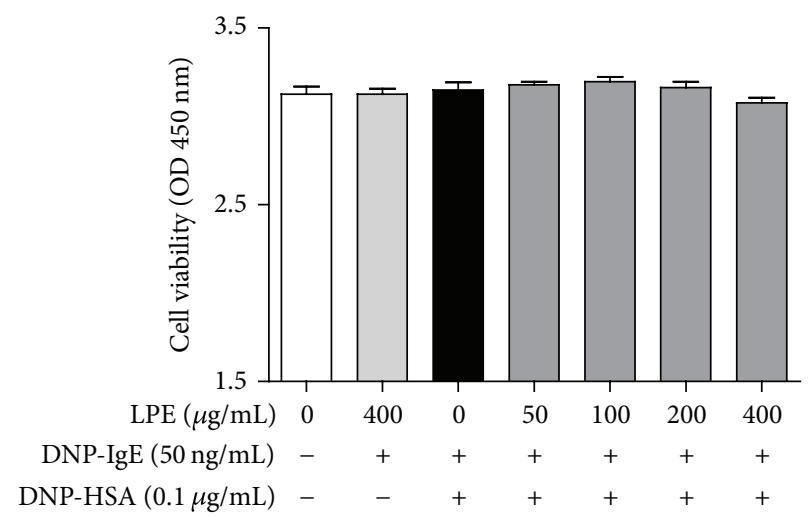

(b)

FIGURE 1: Effect of LPE on degranulation and cell viability in IgE-mediated RBL-2H3 cells. RBL-2H3 cells were seeded on a 24 -well plate $\left(1 \times 10^{5}\right.$ cells/well $)$ or a 96-well plate $\left(1 \times 10^{4}\right.$ cells/well $)$ in MEM- $\alpha$ with $10 \% \mathrm{FBS}$ at $37^{\circ} \mathrm{C}$ overnight and further incubated with DNP-IgE for $24 \mathrm{~h}$. IgE-sensitized cells were preincubated with LPE (0 to $400 \mu \mathrm{g} / \mathrm{mL})$ for $1 \mathrm{~h}$ and then stimulated with DNP-HSA $(0.1 \mu \mathrm{g} / \mathrm{mL})$ for $4 \mathrm{~h}$. $\beta$-Hexosaminidase activity and cell viability were determined as described in Section 2. Data are the mean \pm SD values of triple or octuple determinations. ${ }^{* *} P<0.01$ versus DNP-HSA-treated group. (a) $\beta$-Hexosaminidase; (b) cell viability.

an Imaging system (ChemiDoc Touch Imaging System, BioRad, Hercules, CA, USA). The density levels of target proteins identified by a protein standard size marker (BIOFACT, Daejeon, Korea) were compared to those of a loading control $(\beta$-actin). The density of target protein bands was measured using Image software (version $1.49 \mathrm{v}$ for Windows, $\mathrm{NIH}$, USA).

2.10. Statistical Analyses. All experimental results were reported as means $\pm \mathrm{SD}$. One-way analysis of variance (ANOVA) was used for multiple comparisons (GraphPad Prism version 5.03 for Windows, San Diego, CA, USA). If there was a significant variation between treated groups, the Dunnett test was applied. Differences at the ${ }^{*} P<0.05$ and ${ }^{* *} P<0.01$ levels were considered statistically significant.

\section{Results}

3.1. Profiles of Total Phenolic Compounds and Flavonoids in $L P E$. First, we investigated whether LPE includes phenolic compounds and flavonoids because these compounds from various mistletoes are known to possess various beneficial effects, such as antioxidant, neuroprotection, and anticancer effects [3]. LPE contained total phenolic compounds (10.72 \pm $0.06 \mathrm{mg} / \mathrm{g}$ dry weight, the mean $\pm \mathrm{SD}$ values of triple determinations) and total flavonoids $(56.20 \pm 0.40 \mathrm{mg} / \mathrm{g}$ dry weight, the mean \pm SD values of triple determinations). These results indicate that LPE contains phenolic compounds and flavonoids that may be closely associated with the beneficial actions of Loranthus parasiticus.

\subsection{Inhibitory Effect of LPE on IgE-Mediated Degranulation} in $\mathrm{RBL}-2 \mathrm{H} 3$ Cells. Because we found that LPE included total phenolic compounds and flavonoids, we investigated whether LPE can inhibit degranulation of IgE-activated mast cells. When IgE-sensitized RBL-2H3 cells were preincubated with various concentrations of LPE (0 to $400 \mu \mathrm{g} / \mathrm{mL}$ ) prior to antigen challenge $(0.1 \mu \mathrm{g} / \mathrm{mL}$ DNP-HSA $)$, LPE inhibited the release of $\beta$-hexosaminidase, a common biomarker of degranulation, in a concentration-dependent manner with an $\mathrm{IC}_{50}$ value of $184.5 \mu \mathrm{g} / \mathrm{mL}$ (Figure $1(\mathrm{a})$ ). In addition, $400 \mu \mathrm{g} / \mathrm{mL}$ LPE dramatically suppressed IgE-mediated degranulation to a similar level as the control without significant cytotoxicity (Figure 1(b)). Therefore, these results indicate that LPE possesses antiallergic activity at noncytotoxic concentrations by inhibiting degranulation of IgE-activated mast cells.

3.3. Inhibitory Effects of LPE on Production of Pro-Inflammatory Mediators. Proinflammatory mediators are released from granules in IgE-activated mast cells upon stimulation with antigens $[9,18]$. In addition, the mediators are closely associated with the progression of allergic diseases, such as asthma, allergic rhinitis, and atopic dermatitis [8-10, 18]. Therefore, we investigated the effect of LPE on the production of proinflammatory cytokines, such as TNF- $\alpha$ and IL-4, and eicosanoids, such as $\mathrm{PGE}_{2}, \mathrm{PGD}_{2}$, and $\mathrm{LTC}_{4}$. When IgEsensitized RBL-2H3 cells were preincubated with LPE before antigen challenge, LPE significantly inhibited the formation of TNF- $\alpha\left(\mathrm{IC}_{50}, 84.27 \mu \mathrm{g} / \mathrm{mL}\right.$, Figure $\left.2(\mathrm{a})\right)$, IL-4 ( $\mathrm{IC}_{50}$, $93.43 \mu \mathrm{g} / \mathrm{mL}$, Figure $2(\mathrm{~b}))$, and $\mathrm{LTC}_{4}\left(\mathrm{IC}_{50}, 43.27 \mu \mathrm{g} / \mathrm{mL}\right.$, Figure $3(\mathrm{~b}))$. In addition, LPE suppressed the biosynthesis of $\mathrm{PGE}_{2}\left(\mathrm{IC}_{50}, 84.10 \mu \mathrm{g} / \mathrm{mL}\right.$, Figure $\left.3(\mathrm{a})\right)$ and $\mathrm{PGD}_{2}$ (Figure 3(c)) in a dose-dependent manner up to $200 \mu \mathrm{g} / \mathrm{mL}$, whereas $400 \mu \mathrm{g} / \mathrm{mL}$ LPE gradually increases the levels of $\mathrm{PGE}_{2}$ and $\mathrm{PGD}_{2}$. It seems that the effects of LPE at $400 \mu \mathrm{g} / \mathrm{mL}$ may lead to activation of activity or/and expression of $\mathrm{PGE}_{2}$ and $\mathrm{PGD}_{2}$ synthases. Therefore, further studies are required to develop LPE as a phytomedicine for allergic therapy. Taken together, these findings suggest that LPE inhibits the formation of allergic inflammatory mediators, including proinflammatory cytokines and eicosanoids, but exhibits mild side effects on formation of $\mathrm{PGD}_{2}$ and $\mathrm{PGE}_{2}$ at a high concentration $(400 \mu \mathrm{g} / \mathrm{mL})$. Consequently, LPE 


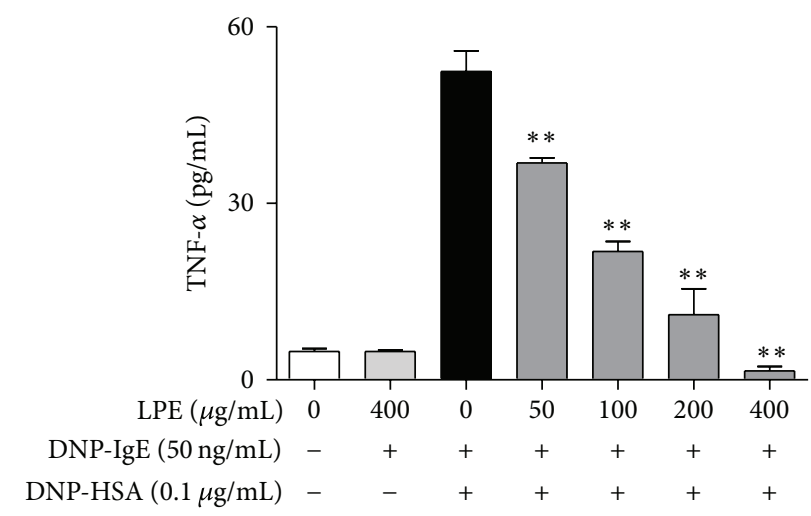

(a)

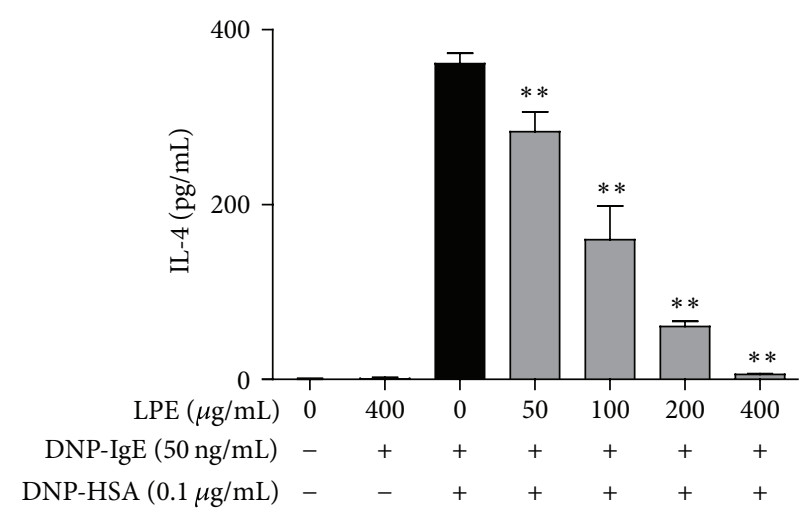

(b)

FIGURE 2: Inhibitory effect of LPE on proinflammatory cytokines. IgE-sensitized RBL-2H3 cells were preincubated with LPE for $1 \mathrm{~h}$ prior to antigen challenge. TNF- $\alpha$ and IL-4 levels were determined as described in Section 2. Data are mean \pm SD values of triple determinations. ${ }^{* *} P<0.01$ versus DNP-HSA-treated group. (a) TNF- $\alpha$; (b) IL-4.

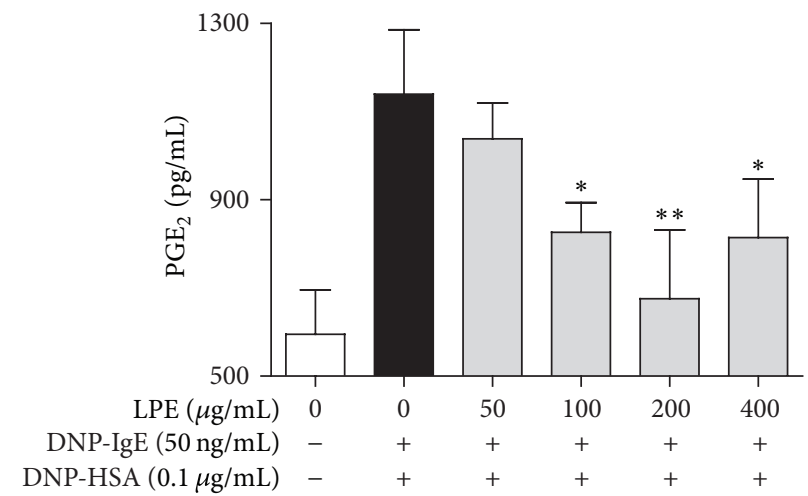

(a)

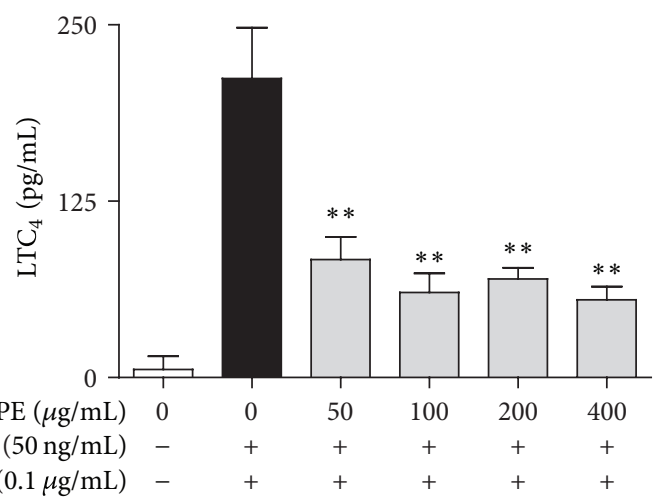

(b)

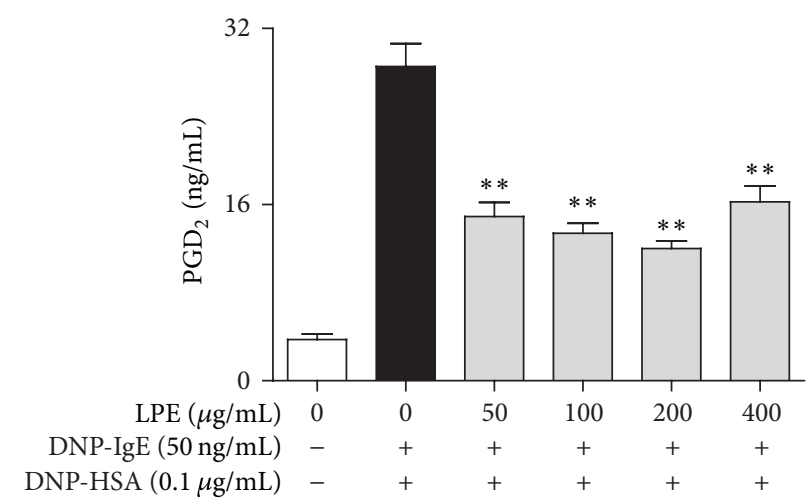

(c)

FIGURE 3: Inhibitory effect of LPE on proinflammatory lipid mediators. IgE-sensitized RBL-2H3 cells were preincubated with LPE for $1 \mathrm{~h}$ before antigen treatment. $\mathrm{PGE}_{2}, \mathrm{LTC}_{4}$, and $\mathrm{PGD}_{2}$ levels were determined as described in Section 2 . Data are mean $\pm \mathrm{SD}$ values of triple determinations. ${ }^{*} P<0.05$ and ${ }^{* *} P<0.01$ versus DNP-HSA-treated group. (a) $\mathrm{PGE}_{2}$; (b) $\mathrm{LTC}_{4}$; (c) $\mathrm{PGD}_{2}$.

may block acute or chronic inflammation caused by allergic inflammatory mediators in allergic diseases.

3.4. Regulatory Effects of LPE on Enzymes for Eicosanoid Biosynthesis. Next, we assessed the effect of LPE on enzymes responsible for biosynthesis of eicosanoids, such as $\mathrm{PGE}_{2}$,
$\mathrm{PGD}_{2}$, and $\mathrm{LTC}_{4}$, which induce chronic inflammation in allergic diseases $[10,19,20]$. To address the issue, we examined the effect of LPE on phosphorylation of $\mathrm{CPLA}_{2}$, a rate-limiting enzyme of the arachidonate cascade, and 5$\mathrm{LO}$, a rate-determining enzyme of leukotriene biosynthesis, and the expression of COX-2, a rate-controlling enzyme of 

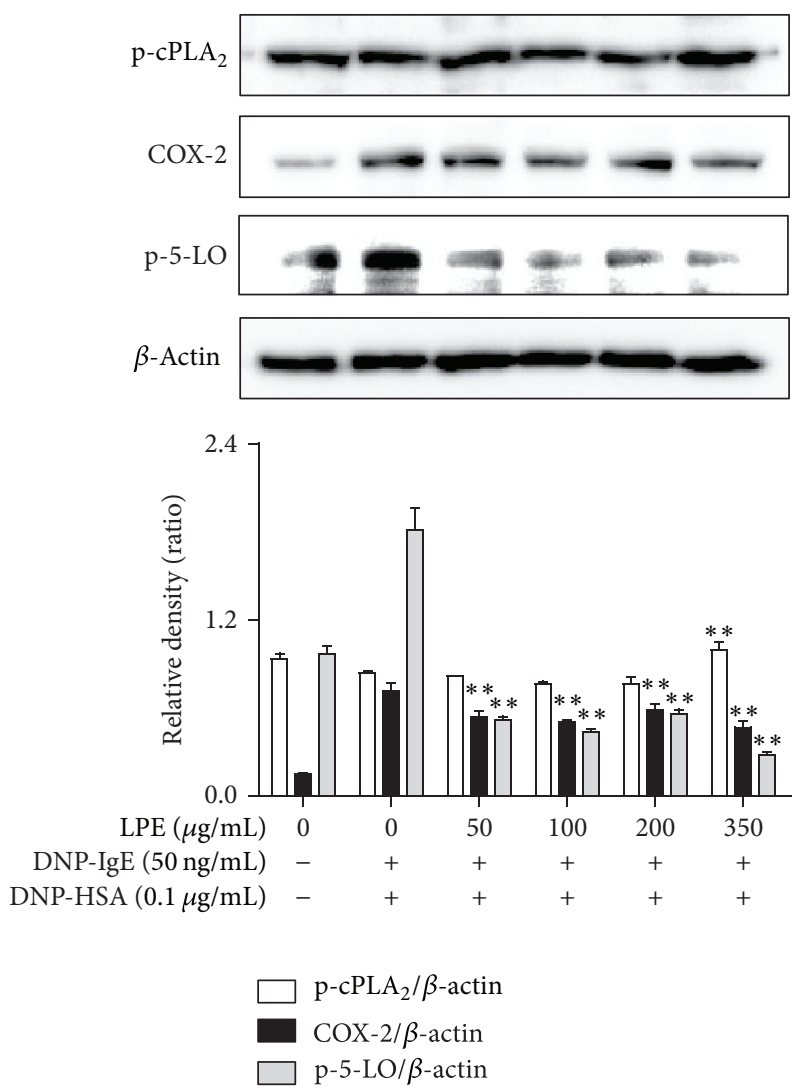

FIGURE 4: Effect of LPE on phosphorylation or expression of ratelimiting enzymes in the arachidonate cascade. RBL-2H3 cells were seeded on a 6 -well plate $\left(5 \times 10^{5}\right.$ cells/well $)$ in MEM- $\alpha$ with $10 \%$ FBS at $37^{\circ} \mathrm{C}$ overnight and further incubated with DNP-IgE for $24 \mathrm{~h}$. IgE-sensitized RBL-2H3 cells were preincubated with LPE ( 0 to $350 \mu \mathrm{g} / \mathrm{mL}$ ) prior to antigen challenge. The above cells were washed with $1 \mathrm{x}$ DPBS and lysed with cell lysis buffer. The expression of $\mathrm{p}$ cPLA $_{2}$, p-5-LO, COX-2, or $\beta$-actin was determined as described in Section 2. Similar results were obtained in three independent experiments. ${ }^{* *} P<0.01$ versus DNP-HSA-treated group.

prostaglandin biosynthesis. As shown in Figure 4, when IgEsensitized RBL-2H3 cells were preincubated with various concentrations of LPE for $4 \mathrm{~h}$ before antigen exposure, LPE inhibited phosphorylation of 5-LO and expression of COX-2 but not phosphorylation of $\mathrm{CPLA}_{2}$. These results indicate that LPE inhibits the biosynthesis of eicosanoids, including $\mathrm{PGE}_{2}$, $\mathrm{PGD}_{2}$, and $\mathrm{LTC}_{4}$, through the regulation of 5-LO and COX2 activation in prostaglandin and leukotriene biosynthesis, respectively.

3.5. Regulatory Effect of LPE on the Activation of the FcERI Signaling Cascade. Finally, because LPE suppressed the ratelimiting enzymes involved in prostaglandin and leukotriene biosynthesis in the late phase $(4 \mathrm{~h})$, we further examined the rate-limiting and intermediate proteins related with the FceRI signaling cascade in the early phase $(10 \mathrm{~min})$ because the activation of eicosanoid biosynthesis is implicated in the FceRI signaling cascade in IgE-activated mast cells [17, 21]. As shown in Figure 5(a), when IgE-sensitized RBL-2H3 cells preincubated with LPE were activated by antigen for $10 \mathrm{~min}$, LPE reduced the phosphorylation level of Syk but not Fyn and Lyn, which are initial proteins in the FceRI signaling cascade. Furthermore, LPE significantly inhibited the phosphorylation level of PLC $\gamma 1 / 2$ and $\mathrm{PKC} \delta$, which are related to the degranulation process (Figure 5(b)), and decreased the phosphorylation levels of ERK, JNK, p38, and Akt, which are related to expression of proinflammatory cytokines (Figure 5(c)). These results suggest that LPE can block activation of the FceRI signaling cascade by suppressing the activity of Syk in IgE-activated mast cells.

\section{Discussion}

The action of Loranthus parasiticus in allergic reaction is unknown, although it has some beneficial effects [3]. Thus, the present study demonstrates that Loranthus parasiticus has antiallergic properties in IgE-activated mast cells based on in vitro tests. In addition, such effects of Loranthus parasiticus are caused by total phenolic compounds or/and flavonoids, because triterpenes, sesquiterpene lactones, or flavonoids derived from Loranthus parasiticus are associated with numerous beneficial effects [3]. Phenolic compounds and flavonoids attenuate allergic responses in IgE-activated mast cells $[14,17]$. Nevertheless, the effects of components in Loranthus parasiticus on allergic reactions have not been reported.

One possible mechanism for the antiallergic activities of LPE may be related to a direct suppression of activation of the FceRI signaling cascade in IgE-activated mast cells because the degranulation initiation of IgE-activated mast cells is closely associated with the activation of the FceRI receptor located on the plasma membrane of the cells [7, 8]. Consequently, IgE-activated mast cells liberate various inflammatory mediators, such as IL- $4, \mathrm{TNF}-\alpha$, histamine, prostaglandins, and leukotrienes $[9,10,18,19]$. In support of this, in our study, when IgE-sensitized mast cells were preincubated with LPE prior to antigen challenge, LPE decreased IL-4, TNF- $\alpha, \mathrm{PGD}_{2}, \mathrm{PGE}_{2}$, and $\mathrm{LTC}_{4}$ production. In addition, LPE inhibited activation of Syk, a rate-limiting intermediate protein of the FceRI signaling cascade [8]. Moreover, LPE also suppressed activation of the PLC $\gamma 1 / 2-\mathrm{PKC} \delta$ pathway, which is related to degranulation process [8], and Akt, p38, ERK, and JNK, which are associated with cytokine expression [8], in IgE-activated mast cells. Therefore, the activation of both the PLC $\gamma 1 / 2-\mathrm{PKC} \delta$ pathway and intermediate proteins is directly associated with activation of the FceRI signaling cascade. Taken together, the antiallergic action of LPE is closely associated with inhibiting Syk activation in the FceRI signaling cascade. Therefore, LPE may directly regulate activation of the FceRI signaling cascade through inhibition of Syk activation in IgE-activated mast cells.

Another possible mechanism for the antiallergic activities of LPE may be associated with suppression of arachidonate cascade activation in IgE-activated mast cells because the above cells can produce various proinflammatory lipid mediators, such as $\mathrm{LTC}_{4}, \mathrm{PGD}_{2}$, and $\mathrm{PGE}_{2}$ [8-10], and release them from numerous granules $[11,12]$. Moreover, these lipid mediators lead to chronic inflammation in allergic diseases, 

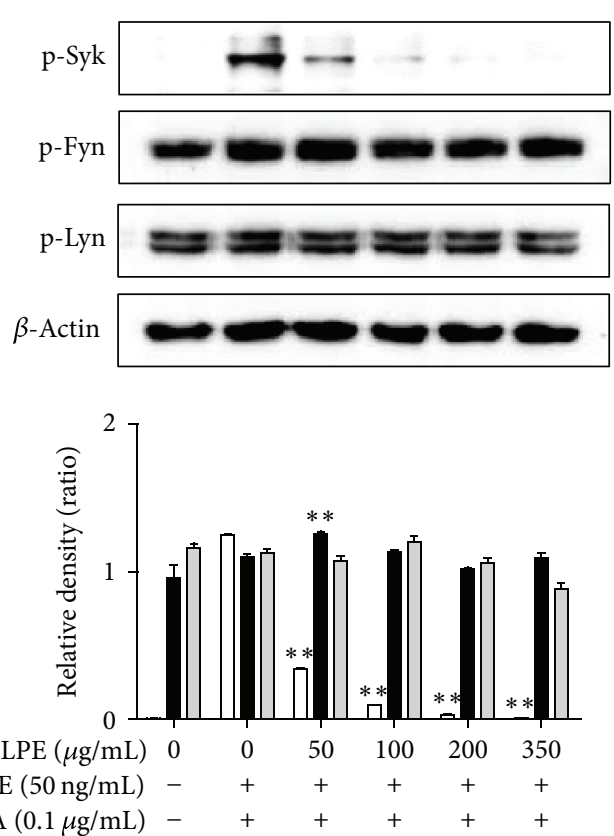

\begin{tabular}{|c|c|c|c|c|c|}
\hline DNP-IgE $(50 \mathrm{ng} / \mathrm{mL})$ & - & + & + & + & + \\
\hline DNP-HSA $(0.1 \mu \mathrm{g} / \mathrm{mL})$ & - & + & + & + & + \\
\hline
\end{tabular}
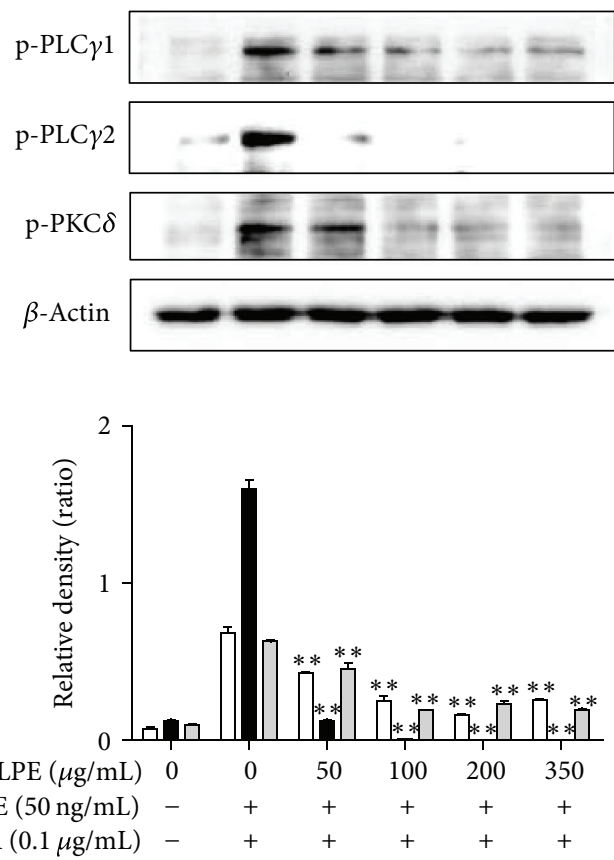

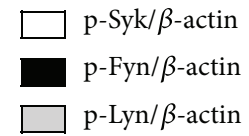

(a)

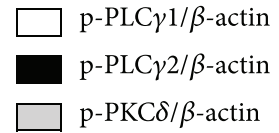

(b)

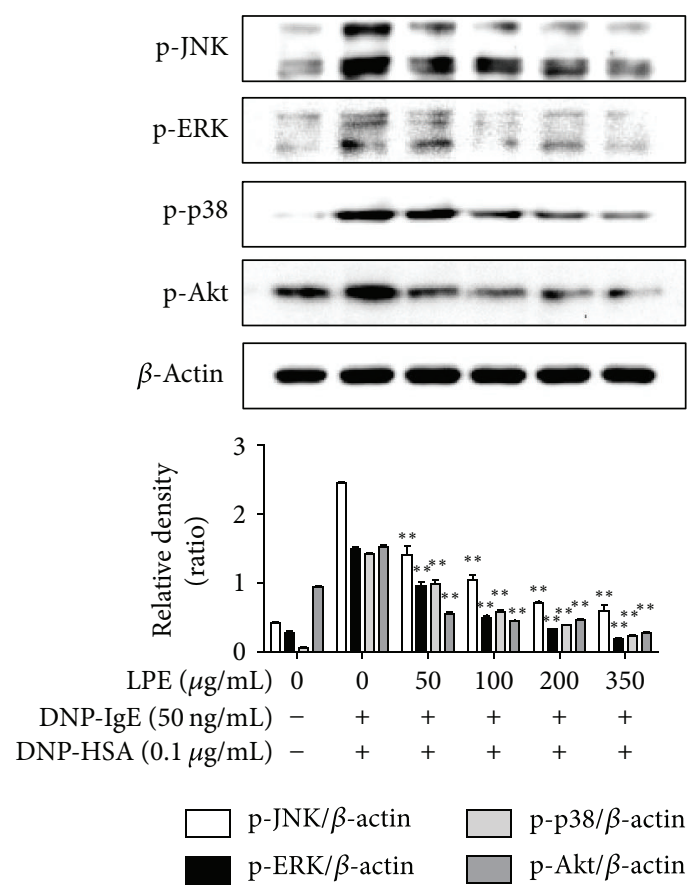

(c)

FIGURE 5: Effect of LPE on phosphorylation of rate-limiting or intermediate proteins in the FceRI signaling cascade. IgE-sensitized RBL-2H3 cells were preincubated with LPE for $1 \mathrm{~h}$ and then stimulated with antigen for $10 \mathrm{~min}$. The above cells were washed with $1 \mathrm{x}$ DPBS and lysed with cell lysis buffer. The expression of p-Lyn, p-Fyn, p-Syk, p-ERK, p-JNK, p-p38, p-Akt, p-PLC $\gamma 1$, p-PLC $\gamma 2$, p-PKC $\delta$, or $\beta$-actin was determined as described in Section 2. Similar results were obtained in three independent experiments. ${ }^{* *} P<0.01$ versus DNP-HSA-treated group. (a) p-Syk, p-Fyn, and p-Lyn; (b) p-PLC $\gamma 1 / 2$ and p-PKC $\delta$; (c) p-JNK, p-ERK, p-p38, and p-Akt. 
such as asthma and allergic rhinitis [7, 10]. Therefore, the regulation of eicosanoid formation is another important factor for the antiallergic properties of LPE. Consistently, LPE reduced biosynthesis of $\mathrm{PGE}_{2}, \mathrm{PGD}_{2}$, and $\mathrm{LTC}_{4}$ and suppressed expression of COX-2, a rate-limiting enzyme for prostaglandin biosynthesis [17], and activation of 5-LO, an initial enzyme for leukotriene biosynthesis [17], in IgEactivated mast cells. These findings suggest that LPE inhibits the formation of eicosanoids through regulation of ratelimiting enzymes, such as COX-2 and 5-LO. In addition, LPE may regulate other enzymes related with eicosanoid biosynthesis with the exception of $\mathrm{CPLA}_{2}$. Such effects of LPE may contribute to the enhancement of its antiallergic properties in allergic responses.

\section{Conclusions}

In this study, we revealed, for the first time, a novel role of LPE in IgE-mediated allergic reactions. We found that LPE has antiallergic efficacy in IgE-activated mast cells and contains numerous total phenolic compounds and flavonoids that are potentially responsible for antiallergic actions. The mechanisms of its antiallergic properties include various targets, such as Syk, Akt, ERK, JNK, p38, PLC $\gamma 1 / 2, \mathrm{PKC} \delta$, 5-LO, and COX-2. LPE can be used to develop a functional food or a phytomedicine for alleviating allergic diseases. Furthermore, it is necessary to identify the active compounds in Loranthus parasiticus that possess antiallergic action.

\section{Abbreviations}

5-LO: 5-Lipoxygenase

Akt: $\quad$ Protein kinase B

COX-2: Cyclooxygenase-2

cPLA 2 : Cytosolic phospholipase $\mathrm{A}_{2}$

ERK: Extracellular signal-regulated kinase 1/2

Fyn: $\quad$ Feline yes-related protein

HSA: Human serum albumin

IgE: Immunoglobulin $\mathrm{E}$

IL-4: Interleukin-4

JNK: c-Jun $N$-terminal kinase $1 / 2$

LPE: $\quad$ Extract of Loranthus parasiticus

LTC $_{4}$ : Leukotriene $\mathrm{C}_{4}$

Lyn: $\quad$ Src family protein kinase

$\mathrm{PGE}_{2}$ : Prostaglandin $\mathrm{E}_{2}$

$\mathrm{PGD}_{2}$ : Prostaglandin $\mathrm{D}_{2}$

PKC $\delta$ : Protein kinase $\mathrm{C} \delta$

PLC $\gamma$ : Phospholipase $\mathrm{C} \gamma$

Syk: $\quad$ Spleen tyrosine kinase

TNF- $\alpha$ : Tumor necrosis factor- $\alpha$.

\section{Competing Interests}

The authors declare that they have no conflict of interests.

\section{Acknowledgments}

This work was supported by Grant K16281 from the Korea Institute of Oriental Medicine, Ministry of Education, Science and Technology (MEST), Republic of Korea.

\section{References}

[1] K.-W. Kim, S.-H. Yang, and J.-B. Kim, "Protein fractions from korean mistletoe (Viscum Album coloratum) extract induce insulin secretion from pancreatic beta cells," Evidence-based Complementary and Alternative Medicine, vol. 2014, Article ID 703624, 2014.

[2] K. Hwang, J. Kim, Y. Choi, K. Choj, and K. Park, "One of the Korean mistletoe species, Loranthus yadoriki Sieb. exhibited potent inhibitory activities against monoamine oxidases," Planta Medica, vol. 77, no. 12, article PF63, 2011.

[3] S. Z. Moghadamtousi, M. N. A. Kamarudin, C. K. Chan, B. H. Goh, and H. A. Kadir, "Phytochemistry and biology of Loranthus parasiticus Merr, a commonly used herbal medicine," The American Journal of Chinese Medicine, vol. 42, no. 1, pp. 2335, 2014.

[4] R. W. Gorter, M. Van Wely, M. Stoss, and U. Wollina, "Subcutaneous infiltrates induced by injection of mistletoe extracts (Iscador)," American Journal of Therapeutics, vol. 5, no. 3, pp. 181-187, 1998.

[5] S. Zorofchian Moghadamtousi, M. Hajrezaei, H. Abdul Kadir, and K. Zandi, "Loranthus micranthus Linn.: biological activities and phytochemistry," Evidence-Based Complementary and Alternative Medicine, vol. 2013, Article ID 273712, 9 pages, 2013.

[6] D. Z. H. Wong, H. A. Kadir, and S. K. Ling, "Bioassayguided isolation of neuroprotective compounds from Loranthus parasiticus against $\mathrm{H}_{2} \mathrm{O}_{2}$-induced oxidative damage in NG10815 cells," Journal of Ethnopharmacology, vol. 139, no. 1, pp. 256264, 2012.

[7] A. M. Gilfillan and M. A. Beaven, "Regulation of mast cell responses in health and disease," Critical Reviews in Immunology, vol. 31, no. 6, pp. 475-530, 2011.

[8] A. M. Gilfillan and C. Tkaczyk, "Integrated signalling pathways for mast-cell activation," Nature Reviews Immunology, vol. 6, no. 3, pp. 218-230, 2006.

[9] W. E. Paul, "Interleukin-4 production by Fc epsilon R+ cells," Skin Pharmacology, vol. 4, supplement 1, pp. 8-14, 1991.

[10] T. C. T. M. van der Pouw Kraan, L. C. M. Boeije, R. J. T. Smeenk, J. Wijdenes, and L. A. Aarden, "Prostaglandin-E2 is a potent inhibitor of human interleukin 12 production," The Journal of Experimental Medicine, vol. 181, no. 2, pp. 775-779, 1995.

[11] M. K. Church and F. Levi-Schaffer, "The human mast cell," Journal of Allergy and Clinical Immunology, vol. 99, no. 2, pp. 155-160, 1997.

[12] D. D. Metcalfe, M. Kaliner, and M. A. Donlon, "The mast cell," Critical Reviews in Immunology, vol. 3, no. 1, pp. 23-74, 1981.

[13] T. H. Chung, T. J. Kang, W. K. Cho et al., "Effectiveness of the novel herbal medicine, KIOM-MA, and its bioconversion product, KIOM-MA128, on the treatment of atopic dermatitis," Evidence-Based Complementary And Alternative Medicine, vol. 2012, Article ID 762918, 9 pages, 2012.

[14] J.-M. Yoo, D.-E. Sok, and M. R. Kim, "Anti-allergic action of aged black garlic extract in RBL-2H3 cells and passive cutaneous anaphylaxis reaction in mice," Journal of Medicinal Food, vol. 17, no. 1, pp. 92-102, 2014.

[15] Y. Morita and R. P. Siraganian, "Inhibition of IgE-mediated histamine release from rat basophilic leukemia cells and rat mast cells by inhibitors of transmethylation," The Journal of Immunology, vol. 127, no. 4, pp. 1339-1344, 1981.

[16] M. Ishiyama, H. Tominaga, M. Shiga, K. Sasamoto, Y. Ohkura, and $\mathrm{K}$. Ueno, "A combined assay of cell viability and in vitro 
cytotoxicity with a highly water-soluble tetrazolium salt, neutral red and crystal violet," Biological and Pharmaceutical Bulletin, vol. 19, no. 11, pp. 1518-1520, 1996.

[17] J.-M. Yoo, N. Y. Kim, J. M. Seo et al., "Inhibitory effects of mulberry fruit extract in combination with naringinase on the allergic response in IgE-activated RBL-2H3 cells," International Journal of Molecular Medicine, vol. 33, no. 2, pp. 469-477, 2014.

[18] C. Russo and R. Polosa, "TNF- $\alpha$ as a promising therapeutic target in chronic asthma: a lesson from rheumatoid arthritis," Clinical Science, vol. 109, no. 2, pp. 135-142, 2005.

[19] A. W. Ford-Hutchinson, M. A. Bray, M. V. Doig, M. E. Shipley, and M. J. H. Smith, "Leukotriene B, a potent chemokinetic and aggregating substance released from polymorphonuclear leukocytes," Nature, vol. 286, no. 5770, pp. 264-265, 1980.

[20] E. Nettis, M. D’Erasmo, E. Di Leo et al., “The employment of leukotriene antagonists in cutaneous diseases belonging to allergological field," Mediators of Inflammation, vol. 2010, Article ID 628171, 6 pages, 2010.

[21] Y. Kawakami, J. Kitaura, A. B. Satterthwaite et al., "Redundant and opposing functions of two tyrosine kinases, Btk and Lyn, in mast cell activation," Journal of Immunology, vol. 165, no. 3, pp. 1210-1219, 2000. 


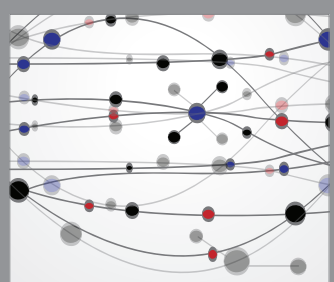

The Scientific World Journal
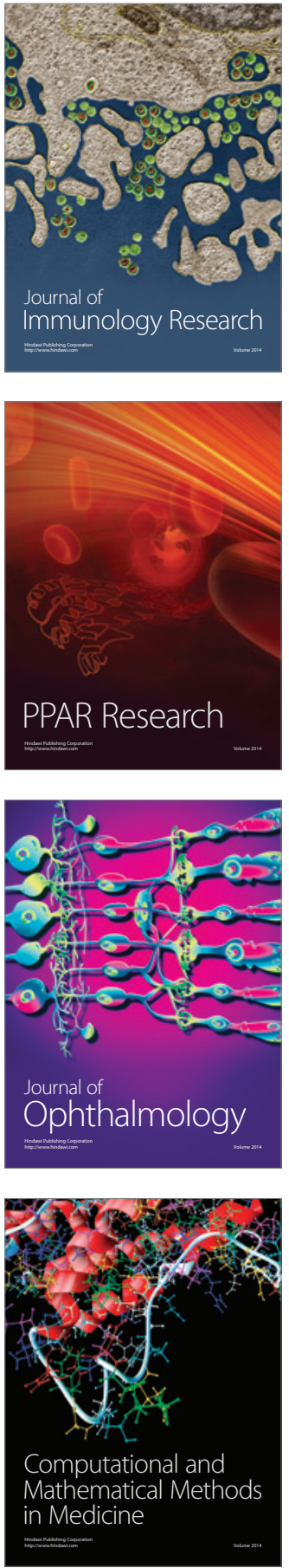

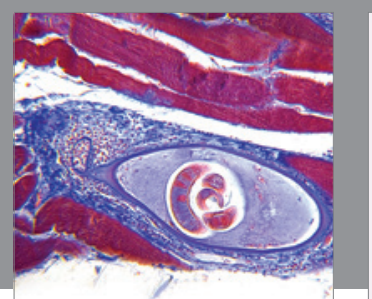

Gastroenterology Research and Practice

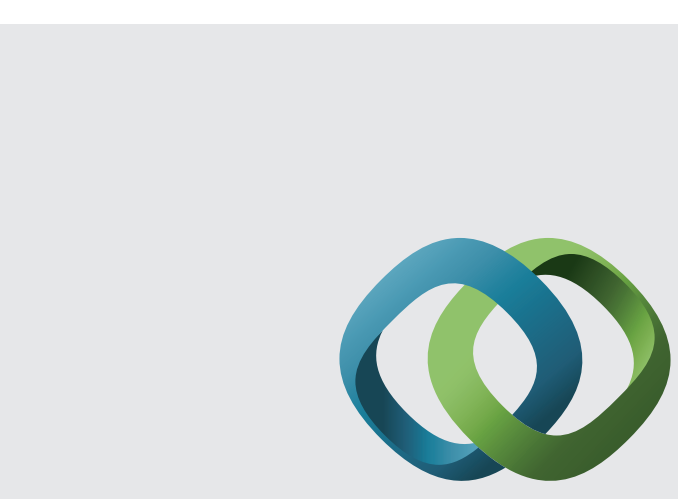

\section{Hindawi}

Submit your manuscripts at

http://www.hindawi.com
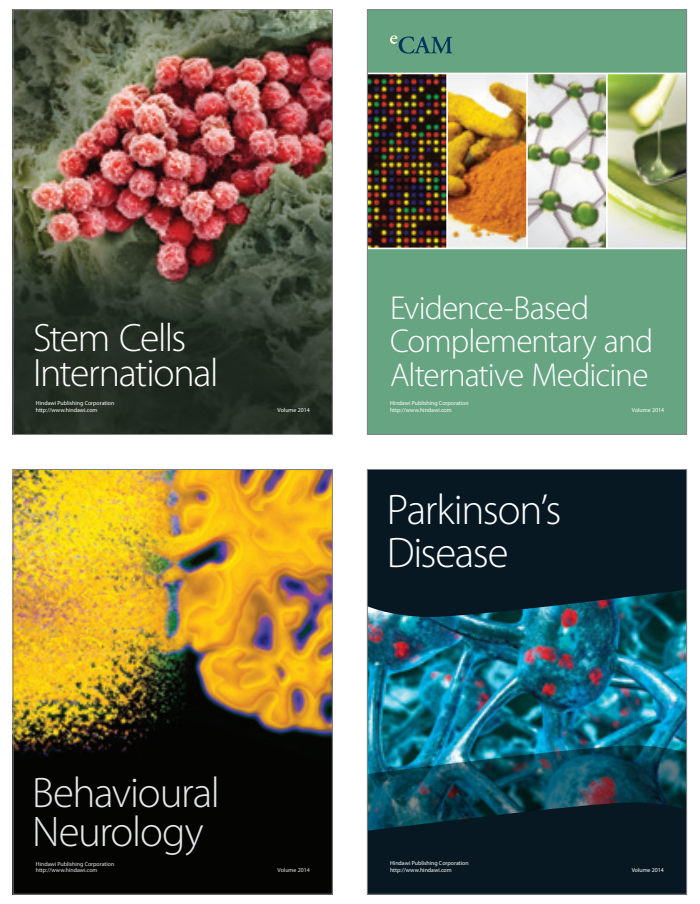
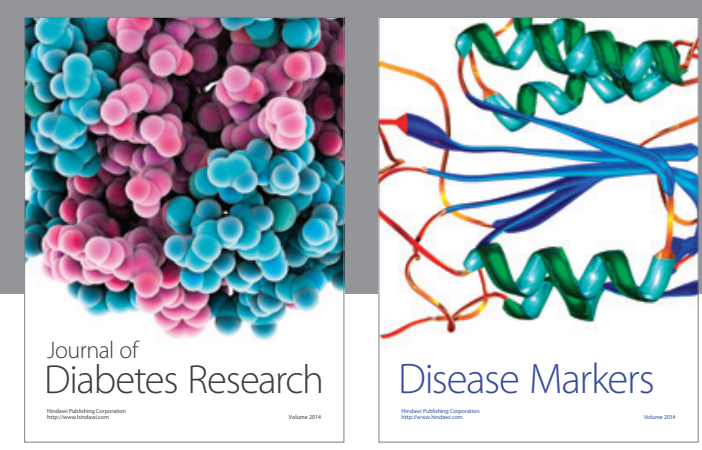

Disease Markers
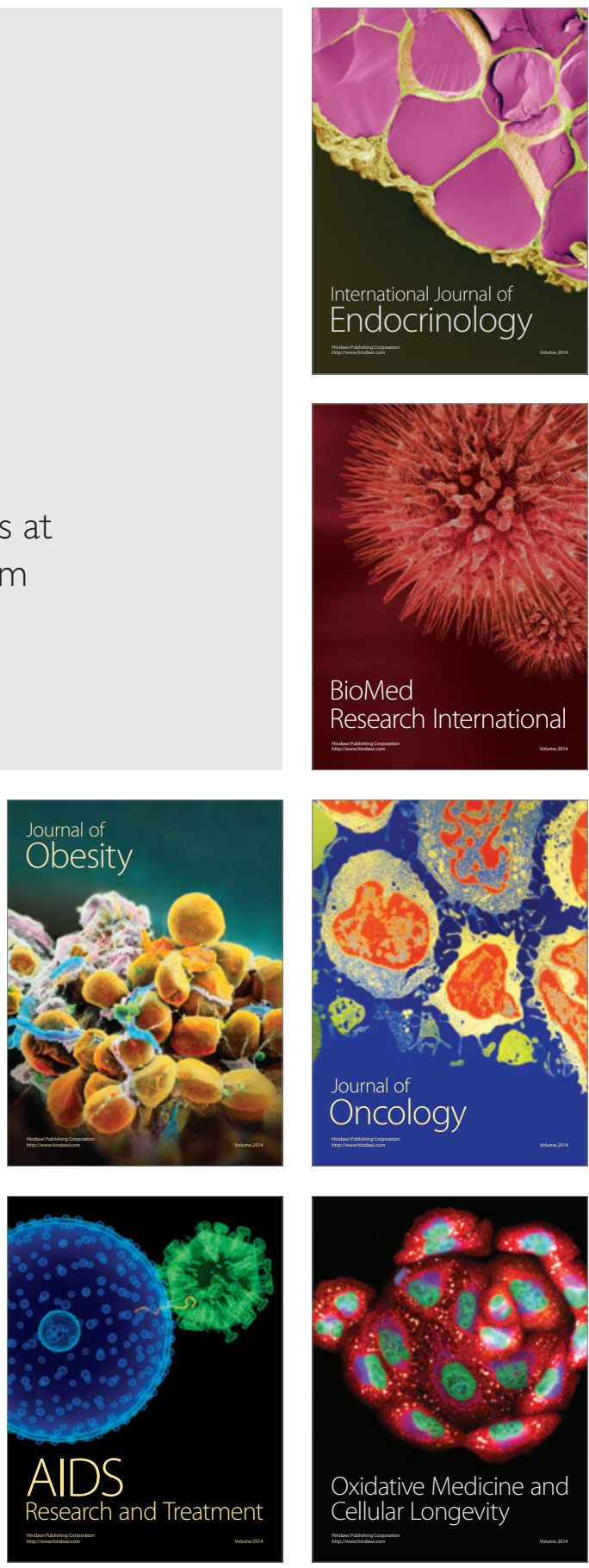